\title{
LVI. On the action of the yellow rays of light on vegetation
}

\section{Robert Harkness Esq.}

To cite this article: Robert Harkness Esq. (1844) LVI. On the action of the yellow rays of light on vegetation, Philosophical Magazine Series 3, 25:167, 339-341, DOI: 10.1080/14786444408645007

To link to this article: http://dx.doi.org/10.1080/14786444408645007

册 Published online: 30 Apr 2009.

Submit your article to this journal $\lceil\pi$

Џ Article views: 2

Q View related articles $\asymp$ 
LV. Notice of the Meteors of the 9 th and 10th of August, 1844, as roitnessed at Bruges. By Thomas Forster, M.B., F.R.A.S.

\section{Dear Sir,}

To Richard Taylor, Esq.

A $S$ many hasty articles respecting the extraordinary quanA tity of meteors seen on the 10th of this month have been inserted in the papers, I send you the particulars of this phænomenon as observed by me at Bruges.

August 9.-Night clear except a few roane clouds. The annual meteors began to appear tonight, but I only counted seventeen of any considerable size.

August 10.- Night clear. I watched the meteors tonight till near daybreak; they began to be visible at half-past 8 o'clock and continued without intermission all night, though most plentiful between 10 and 12 o'clock. Their number was prodigious, amounting to an average of ninety-six per hour, of which I determined about seventy per hour to have a decided point of convergence somewhere about Antares and Scorpio, a circumstance which I think almost as puzzling as their periodic appearance. They were of various colours, and generally left long white trains behind them in their track, but not such large and lasting trains as those left by the meteors of the 10 th of August, 1811 , which I have already described in your Magazine for that year*. August $19,1844$.

I am Sir, yours, \&c.,

T. Forster.

LVI. On the Action of the Yellow Rays of Light on Vegetation. By Robert Harkness, Esq.

To the Editors of the Philosophical Magazine and Journal. Gentlemen,

THE Philosophical Magazine for January contains a paper upon the Action of Light on Vegetation by Dr. Gardner, in which he states that one of the results of his conclusions is, that yellow light by its influence produces the decomposition of carbonic acid and gives rise to the formation of the hydro-carbonaceous compound called chlorophylle. This circumstance is highly probable, for we know that the maximum of light is in this ray, and also that the green colour of vegetables is dependent upon, in a great measure, the intensity of solar light. But in the fourth paragraph of his paper it is

- A curious circumstance.-I find by the journals that the great meteor seen all over England, August 18, 1783, is reported to have been also seen all over Europe. Now I cannot find any account of it on the continent, nor is it mentioned in any of the reports of the Palatine Society under that day. 
mentioned that "turnep seeds were sown, and every grain germinated in the yellow and red rays-the greenest plants were found in yellow light." 'This is directly in opposition to Mr. Hunt, who found in his experiments, "that the yellow and red rays destroy the vital principle in the seed." From this circumstance there appear's to be either some error on the part of one of these gentlemen, or that some circumstances have affected the experiments of the one which have not influenced those of the other. Dr. Gardner supposes the difference to have arisen from the earth being rapidly dried in the experiments of Mr. Hunt, which he considers sufficient to retard or destroy germination.

It appears to me that Dr. Gardner has overlooked one circumstance in his experiments which seem strongly to militate against the production of chlorophylle by yellow light, or else to show that there is some error either in his experiments or in the account which he has published of them; this is, that the seeds of vegetables germinate most rapidly in yellow light. In the paragraph referred to he merely states this in general terms, whilst in giving the results of the other experiments in detail he mentions that seedling plants were operated upon. Now we know, both from the observations of Ingenhousz and Sennebier, as well as from daily experience, that the absence of solar light is one of the conditions almost necessary for the germination of seed, and consequently we should not expect that ray in which the maximum of light is found to facilitate germination, but on the contrary, as in Mr. Hunt's experiments, to retard it.

This, however, is not the only objection to which this statement is liable, for if the yellow ray be the operating cause by which carbonic acid is decomposed and chlorophylle produced, we should also expect that, so far from assisting in germination, it would exercise a highly injurious influence. We know that the presence of oxygen is necessary for the vegetation of seeds, and also that this oxygen is absorbed, and by uniting with a portion of the carbon in the seed reappears in the form of carbonic acid, a process the opposite of that which takes place when chlorophylle is produced. This change is required in order that the amylaceous principle in the seed may be rendered sufficiently soluble for the support of the germ, previous to its being able to obtain the requisite nutriment from the soil; so that, if the decomposition of carbonic acid be owing to the yellow ray, this same ray ought to be the last to produce any effect on the germination of seeds. It appears moreover that seeds as well as fully developed vegetables possess the power when deprived of light of absorbing oxygen and evolving car- 
bonic acid; and to this circumstance we must ascribe the effect of the blue ray as shown by Mr. Hunt's experiments.

I should feel obliged if you would insert this in the Philosophical Magazine, as it would perhaps attract the attention of those who are engaged in experiments on this subject.

Ormskirk, August 21, 1844.

I am, Sir, your obedient Servant,

Roberi Harkness.

LVII. Descriptive Notice of the Morro Velho Mine, Province of Minas Geraës; and on the Relations between the Structure of the Containing Rocks and the Directions of the Shoots of Gold in the Brazilian Mines. By Wildiam Jony Henwoon, C.E., F.R.S., F.G.S., Chief Commissioner of the Gongo Soco Gold Mines*.

rTHE gold mine of Morro Velho is about 48 miles northwest of the city of Ouro Preto and 10 miles south of the town of Sabará: it has been worked by English companies for nearly sixteen years, but unsuccessfully until within three years past.

It is situated on the flank of a mountain of considerable elevation; to the contour of which the metalliferous mass has an approximate parallelism, a circumstance of frequent occurrence in the gold formations of Brazil.

$a$. The rock mostly consists of a dark lead-coloured clayslate, and occasionally contains traces of chlorite, whilst there are some layers of a dark brown colour, and others which are quartzose and have a crystalline structure. The general bearing of the lamination is from N.E. to S.W., and the dip is usually towards the S.E. from $40^{\circ}$ to $70^{\circ}$. One series of joints bears about $\mathrm{E}$. and $W$., and another $\mathrm{N}$. and $\mathrm{S}$. (magnetic).

$b$. The direction, dip, and dimensions of the mass from which the gold is extracted are very irregular, and although it has some characters in common with metalliferous veins (lodes), it has others which more nearly resemble the formations of tin ore at the Saint Ives Consolst, Rosewall Hill †, and Balnoon $\oint$. 'The accompanying ground plan is copied from that used at the mine, and exhibits the peculiarities of this formation more clearly than any description could do.

The most westerly part of the mine is called the Champion Ground, and consists of an assemblage of small veins; these unite with the little Quebra Panella, which dips N. $70^{\circ}-80^{\circ}$, and is, on an average, about eighteen feet wide, although in this respect it varies very much in different parts. Eastward

* Communicated by the Author.

$\uparrow$ Cornwall Geol. Trans., vol. v. p. 21.

₹ Ibid. p. 237.

\$ Ibid. p. 24, 